Check for updates

Cite this: Chem. Sci., 2019, 10, 7982

๑ All publication charges for this article have been paid for by the Royal Society of Chemistry

\section{Electrochemical oxidation induced selective tyrosine bioconjugation for the modification of biomolecules $\uparrow$}

\author{
Chunlan Song, ${ }^{a}$ Kun Liu, ${ }^{a}$ Zhongjie Wang, ${ }^{a}$ Bo Ding, ${ }^{a}$ Shengchun Wang, \\ Yue Weng, ${ }^{* a b}$ Chien-Wei Chiang ${ }^{\star a}$ and Aiwen Lei (iD ${ }^{* a c}$
}

Directly introducing a beneficial functional group into biomolecules under mild, clean and easy-to-handle conditions is of great importance in the field of chemical biology and pharmacology. Herein, we described an electrochemical strategy to perform the bioconjugation of tyrosine residues with phenothiazine derivatives in a rapid and simple manner. In this electrochemical system, various polypeptides and proteins were successfully labelled with excellent site- and chemo-selectivity, and metals, oxidants or additives were also avoided.

Received 7th May 2019

Accepted 7th July 2019

DOI: $10.1039 / \mathrm{c} 9 \mathrm{sc} 02218 \mathrm{j}$

rsc.li/chemical-science

\section{Introduction}

Developing a site-selective, mild and biocompatible reaction for biomolecule modification is an important pursuit in the field of chemical biology, medical chemistry and clinical pharmacology. ${ }^{1}$ Through the attachment of synthetic molecules to a specific position on proteins, bioconjugation can be applied to DNA labeling, antibody-drug modification and protein visualization studies. ${ }^{2}$ The advantage of naturally low abundance of aromatic amino acid residues on protein surfaces would lead to a higher degree of bioconjugation, without changing the overall charge state or redox sensitivity. ${ }^{3}$ However, due to the similarity of their redox potentials and the difficulty of $\mathrm{C}\left(\mathrm{sp}^{2}\right)-\mathrm{H}$ functionalization, ${ }^{4}$ techniques for labeling these aromatic amino acid residues were fewer than those of cysteine and lysine. ${ }^{4 b, c, 5}$ Thus, aromatic amino acid residues still lack efficiency as well as chemo- and site-selective methods to achieve bioconjugation reactions.

As one of the important amino acids, tyrosine can be found in many polypeptides and proteins, such as tyrosine protein kinases, kisspeptin and myoglobin. Because of its low natural abundance in native proteins, tyrosine is also considered as an attractive target for labeling biomolecules. ${ }^{4 d, 6}$ Previously, some approaches have been developed for tyrosine modification, such as Mannich-type reactions, ${ }^{7}$ Pd catalysts, ${ }^{6 a, 8} \mathrm{Ru}$

${ }^{a}$ College of Chemistry and Molecular Sciences, Institute for Advanced Studies (IAS), Wuhan University, Wuhan 430072, P. R. China. E-mail: aiwenlei@whu.edu.cn

${ }^{b}$ National Synchrotron Radiation Research Center (NSRRC), Hsinchu Science Park, Hsinchu, Taiwan

'National Research Center for Carbohydrate Synthesis, Jiangxi Normal University, Nanchang 330022, P. R. China

$\dagger$ Electronic supplementary information (ESI) available. See DOI: $10.1039 / \mathrm{c} 9 \mathrm{sc} 02218 \mathrm{j}$ photocatalysts, ${ }^{9}$ click-like reactions, ${ }^{10}$ etc. ${ }^{11}$ Recently, several strategies for site-selective protein modification based on oxidative coupling have been reported, which could significantly enrich the methodologies of bioconjugation chemistry. ${ }^{6 c, 12}$ Accompanied by a good momentum of organic electrosynthesis in the field of oxidative coupling reactions, electrochemical anodic oxidation provides a green option to prevent the usage of hazardous oxidants and harsh conditions, and sensitive functional groups could also be well tolerated. ${ }^{13}$ Merging electrochemical organic synthesis and bioconjugation chemistry is very promising, and therefore developing multifarious protocols for peptide and protein modification is highly desirable, especially when excellent selectivity and efficiency could be obtained.

On the other hand, as valuable labeling targets, phenothiazine derivatives have been recognized as highly bioactive drugs and chromophores. ${ }^{14}$ The incorporation of phenothiazine into biomolecules would not only demonstrate the advantage of phenothiazines-containing protein drugs, but also potentially lead to chemical probes. Recently, the group of Gouin has demonstrated the electrochemically promoted tyrosine-clickchemistry for protein labeling with a urazole reagent, which significantly improved both the yield and selectivity compared with the original conditions by using a pre-activated reagent. ${ }^{10 e}$ Herein, we described an electrochemically promoted labeling strategy of tyrosine-containing biomolecules with phenothiazine derivatives under simple, mild and clean conditions (Fig. 1a). Initially, in order to gain insight into the relative redox activity of phenothiazine and aromatic amino acids, cyclic voltammetry experiments have been performed (Fig. 1b). The results showed that the oxidation potential of phenothiazine was much lower than that of Tyr, Trp, Phe and His, which indicated that the reaction proceeded through the single-electron oxidation of phenothiazine (PTZ) to generate the nitrogen 
a)

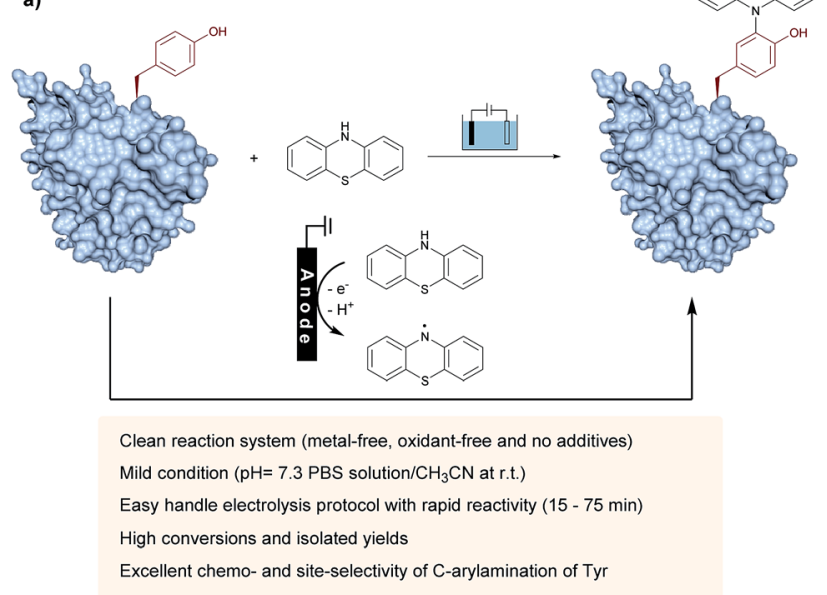

b)

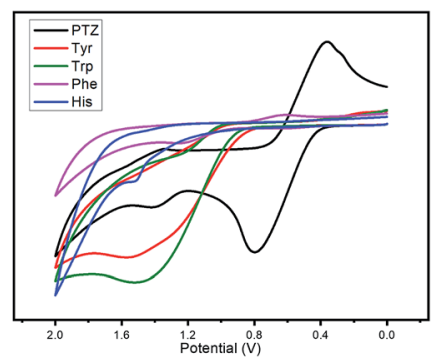

Fig. 1 Discovery of an electrochemical oxidative tyrosine bioconjugation. (a) Proposed pathway: phenothiazine underwent singleelectron oxidization by the anode to generate a radical species, and then coupled with the tyrosine residue of biomolecules to obtain the labeling product. (b) Cyclic voltammograms of 0.005 M PTZ (black), Tyr (red), Trp (green), Phe (purple) and His (blue) at a glassy carbon electrode, in $0.05 \mathrm{M}^{n} \mathrm{Bu}_{4} \mathrm{NBF}_{4}$ in $\mathrm{CH}_{3} \mathrm{CN} / \mathrm{H}_{2} \mathrm{O}$. Scan rate $=100 \mathrm{mV}$ $\mathrm{S}^{-1}$. Reference electrode: $\mathrm{Ag} / \mathrm{AgCl}$. radical. Following radical addition to the ortho-position of phenol would achieve the modification of tyrosine. Due to the less electron-rich position of other aromatic amino acid residues, the radical addition would not be favored. Thus, through choosing phenothiazine as a valuable 'tag' to generate an active species, excellent site- and chemo-selectivity on the protein modification could be obtained.

\section{Results and discussion}

To establish suitable conditions for this electro-oxidative bioconjugation reaction, a protected tyrosine $\mathbf{1 a}$ and phenothiazine 2a were chosen as the model reaction substrates for optimization. Under the electrolysis conditions, the reaction was conducted in a three-necked undivided cell with a graphite rod anode and a nickel plate cathode at $10 \mathrm{~mA}$ constant current for 75 minutes. Product 3a could be obtained in $85 \%$ isolated yield with $\mathrm{Na}_{2} \mathrm{SO}_{4}$ as the electrolyte in $\mathrm{CH}_{3} \mathrm{CN} / \mathrm{H}_{2} \mathrm{O}$ at room temperature (Table 1). To extend the scope of phenothiazine derivatives, a variety of substituted phenothiazines were then applied to couple with tyrosine $\mathbf{1 a}$ under the optimized reaction conditions, which bear halogen (3b), sulfide (3c), trifluoromethyl (3d), acetyl (3e), cyano (3f) and azide (3g) groups. Under these reaction conditions, different electron-donating or electron-withdrawing substituted phenothiazines were all found to be suitable substrates in moderate isolated yields. Remarkably, this method could be extended to azide group substituted phenothiazine which could be applied in further bio-orthogonal reactions.

Furthermore, to explore the polypeptide selectivity and tolerance of this tyrosine labeling reaction, various dipeptides containing tyrosine were introduced into this system. With

Table 1 Substrate scope of phenothiazines for electro-oxidative bioconjugation ${ }^{a}$

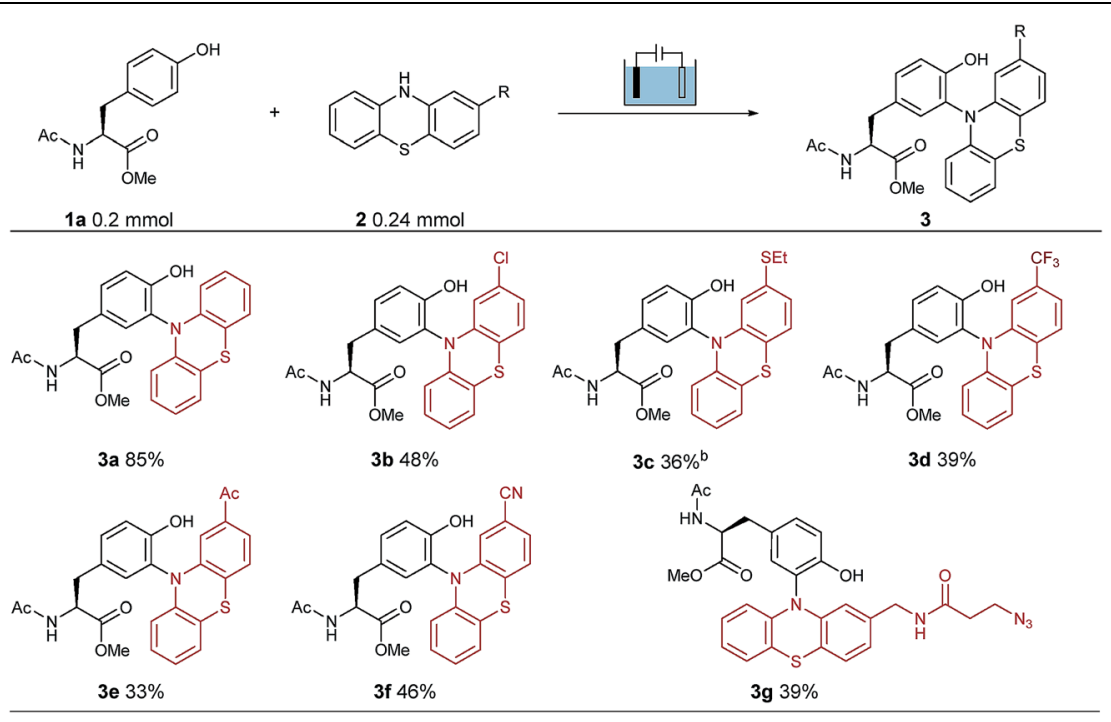

\footnotetext{
${ }^{a}$ Reaction conditions: graphite rod anode, nickel plate cathode, constant current $=10 \mathrm{~mA}, \mathbf{1 a}(1.0$ equiv., $0.20 \mathrm{mmol}), 2$ (1.2 equiv., $\left.0.24 \mathrm{mmol}\right)$, $\mathrm{Na}_{2} \mathrm{SO}_{4}$ (2 equiv., $\left.0.40 \mathrm{mmol}\right), \mathrm{CH}_{3} \mathrm{CN} / \mathrm{H}_{2} \mathrm{O}(6.0 \mathrm{~mL} / 4.0 \mathrm{~mL})$, room temperature, $\mathrm{N}_{2}$, and $75 \mathrm{~min}(Q=45 \mathrm{C}, 2.3 \mathrm{~F})$. Yields of isolated products are shown. ${ }^{b} 10 \mathrm{~mL} \mathrm{CH}{ }_{3} \mathrm{CN}$.
} 
phenothiazine as the coupling partner, these dipeptides made a contribution to the desired bioconjugation reaction in $\mathrm{CH}_{3} \mathrm{CN} / \mathrm{PBS}(\mathrm{pH}=7.3)$ solution without addition of $\mathrm{Na}_{2} \mathrm{SO}_{4}$ (Table 2). Besides the relatively inert glycine (4a) and leucine (4b), this established electrosynthesis protocol was also compatible with the thioether of methionine (4c), phenyl group of phenylalanine (4d), indole $\mathrm{NH}$ of tryptophan (4e), imidazole $\mathrm{NH}$ of histidine (4f), amino group of lysine (4g), hydroxyl group of serine (4h) and carboxylic acid of aspartic acid (4i), indicating a broad functional group tolerance. Meanwhile, the labeling was observed neither on the other aromatic amino acids Trp, His and Phe, nor on the amino, hydroxyl and carboxylic groups of Lys, Ser and Asp. Unfortunately, the Cys-containing dipeptide could only obtain trace amounts of the corresponding product, possibly due to the easily oxidizable property of cysteine under oxidation conditions, leading to the decomposition of the dipeptide. In most cases studied, this electrochemical bioconjugation reaction proceeded perfectly, selectively and cleanly with good isolated yields.

To open an electrosynthetic pathway towards biomolecules such as larger peptides and proteins, we next evaluated the applicability of this electro-oxidative bioconjugation procedure in the synthesis of phenothiazine-modified polypeptides. As a proof-of-concept, the modification of a variety of unprotected peptides 6 from 5-mers to 29-mers have been achieved effectively with excellent conversions (Table 3). We chose the Tyrcontaining RGD peptide as the substrate originally, which was considered as an attractive target for tumor treatment by inducing apoptosis and caspase- 3 activation. This extracellular

Table 2 Survey of amino acid selectivity for electro-oxidative bioconjugation $^{a}$

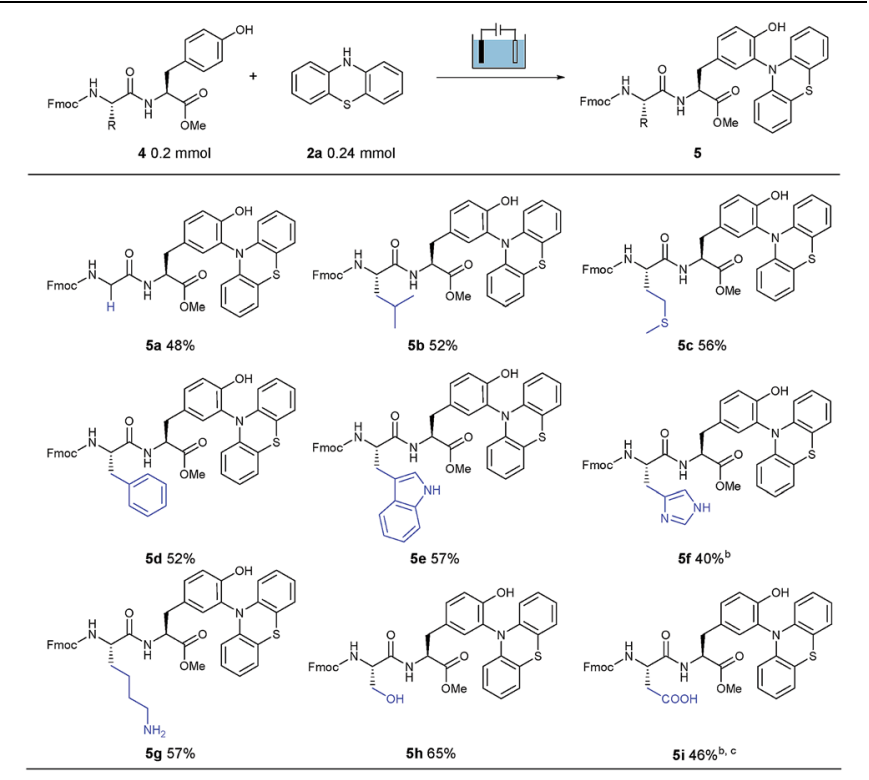

\footnotetext{
${ }^{a}$ Reaction conditions: graphite rod anode, nickel plate cathode, constant current $=10 \mathrm{~mA}, 4(1.0$ equiv., $0.20 \mathrm{mmol}), 2 \mathrm{a}$ (1.2 equiv., $0.24 \mathrm{mmol}), \mathrm{CH}_{3} \mathrm{CN} / \mathrm{PBS}(\mathrm{pH}=7.3)(6.0 \mathrm{~mL} / 4.0 \mathrm{~mL})$, room temperature, $\mathrm{N}_{2}$, and $75 \mathrm{~min}(Q=45 \mathrm{C}, 2.3 \mathrm{~F})$. Yields of isolated products are shown. ${ }^{b} 105$ min. ${ }^{c} \mathrm{CH}_{3} \mathrm{CN} / \mathrm{PBS}(\mathrm{pH}=8.0)$.
}

Table 3 Scope of polypeptides for the electro-oxidative bioconjugation $^{a}$

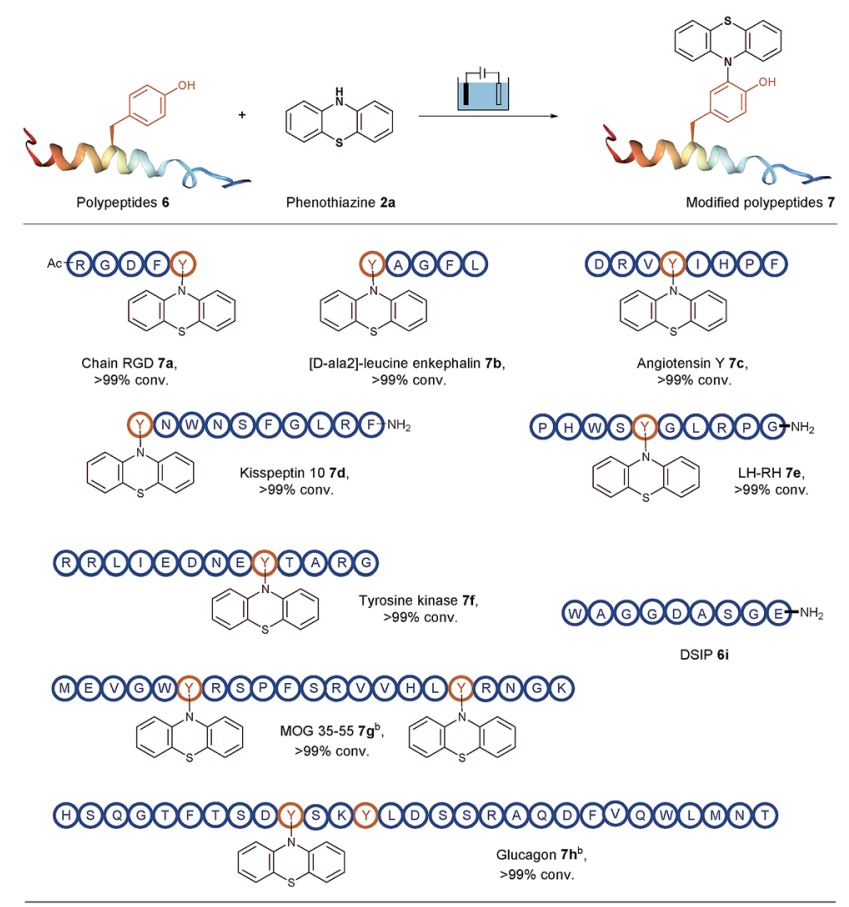

${ }^{a}$ Reaction conditions: graphite rod anode, nickel plate cathode, constant current $=10 \mathrm{~mA}$, polypeptides $6(5 \mathrm{mg})$, phenothiazine $2 \mathrm{a}$ $(10 \mathrm{mg}), \quad \mathrm{CH}_{3} \mathrm{CN} / \mathrm{PBS}(\mathrm{pH}=7.3)(0.75 \mathrm{~mL} / 0.75 \mathrm{~mL})$, room temperature, $\mathrm{N}_{2}$, and $30 \mathrm{~min}$. Conversion of products are shown, as determined by HPLC. ${ }^{b}$ One equiv. of phenothiazine was used.

RGD peptide was used in $\mathrm{CH}_{3} \mathrm{CN} / \mathrm{PBS}(\mathrm{pH}=7.3$ ) to furnish phenothiazine-conjugate $7 \mathrm{a}$ in $99 \%$ conversion. Having established the electrochemical transformation of phenothiazine $\mathbf{2 a}$ with RGD, we then turned our attention to other Tyr-containing polypeptides. For example, acyclic pentapeptide YAGFL was reacted with phenothiazine $\mathbf{2 a}$ under electrolysis conditions, and the bioconjugated product $\mathbf{7 b}$ was obtained in full conversion. We next examined the applicability of this electrolysis methodology for endogenous peptides with biological activity, such as angiotensin Y, kisspeptin 10, LH-RH, tyrosine protein kinases, MOG 35-55 and glucagon. The above peptides contained at least one tyrosine at the positions of the N-terminus, the C-terminus, or a loop. To our delight, all these polypeptides (6c-6h) were successfully tagged with phenothiazine within 30 min at room temperature. It was worth noting that if one equiv. of phenothiazine was added to the reaction solution of $\mathbf{6 g}$ and 6h, respectively, two different results could be observed. Since the two tyrosine residues of $\mathbf{6} \mathbf{g}$ are located in different areas of the peptide, the modification could occur on the both tyrosine residues. For $\mathbf{6 h}$, two tyrosine residues are just located on the $i$ and $i+3$ positions, and the steric influence would make phenothiazine specifically labelled on a less steric hindrance position of Y10. Eventually, the modification of 29-mer peptide glucagon $\mathbf{6 h}$ was conducted the single modified peptide $\mathbf{7 h}$. Meanwhile, a peptide DSIP (WAGGDASGE) 6i which lacks 


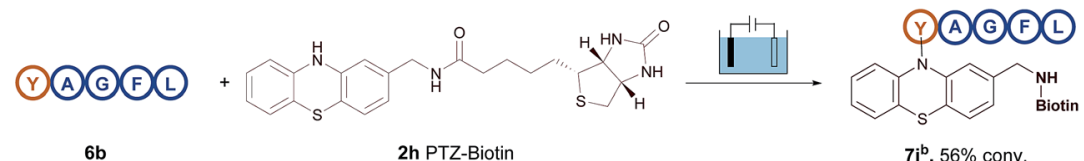

6b

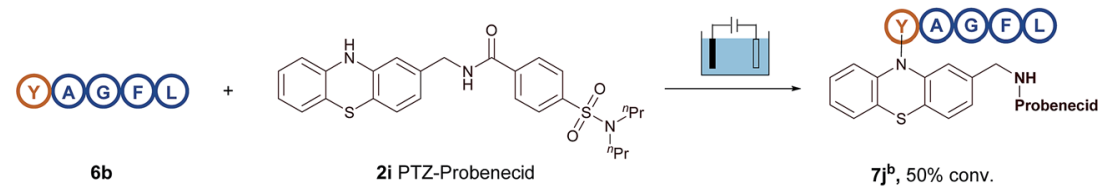

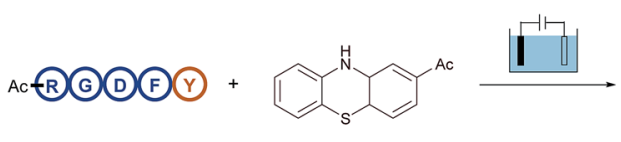

2 e

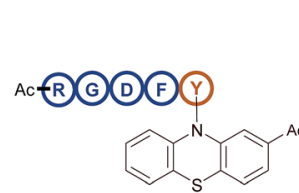

$\mathbf{7} \mathbf{k}^{\mathrm{c}, \mathrm{d}},>99 \%$ conv

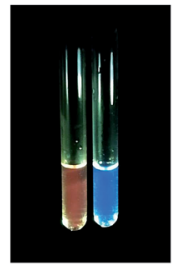

Fig. 2 Additional application of electrochemical oxidative bioconjugation. ${ }^{a}$ Reaction conditions: graphite rod anode, nickel plate cathode, constant current $=10 \mathrm{~mA}$, polypeptides $(5 \mathrm{mg})$, phenothiazine $(10 \mathrm{mg}), \mathrm{CH}_{3} \mathrm{CN} / \mathrm{PBS}(\mathrm{pH}=7.3)(0.75 \mathrm{~mL} / 0.75 \mathrm{~mL})$, room temperature, $\mathrm{N}_{2}$, and 30 min. ${ }^{b}$ Conversion yields of products are shown, as determined by HPLC using diphenylamine as the standard. ${ }^{\mathrm{C}}$ Conversion yields of products are shown, as determined by HPLC using anisic acid as the standard. ${ }^{\mathrm{d}}$ Photographs of the solution of $6 \mathrm{a}$ (right) and modified product 7k (left) with UV lamp excitation.

tyrosine residue was used as a control experiment substrate to confirm the selectivity of the reaction. No desired bioconjugated product could be observed, demonstrating that this protocol had the ability to specifically label tyrosine residues on biomolecules with good site- and chemo-selectivity.
Therefore, all these examples revealed the exceptional siteand chemo-selectivity of the reaction and its application to the peptide-labelled chemistry. In comparison with reported bioconjugation methods, this electrolysis method provided fast kinetics and high productivity in a metal- and additive-free
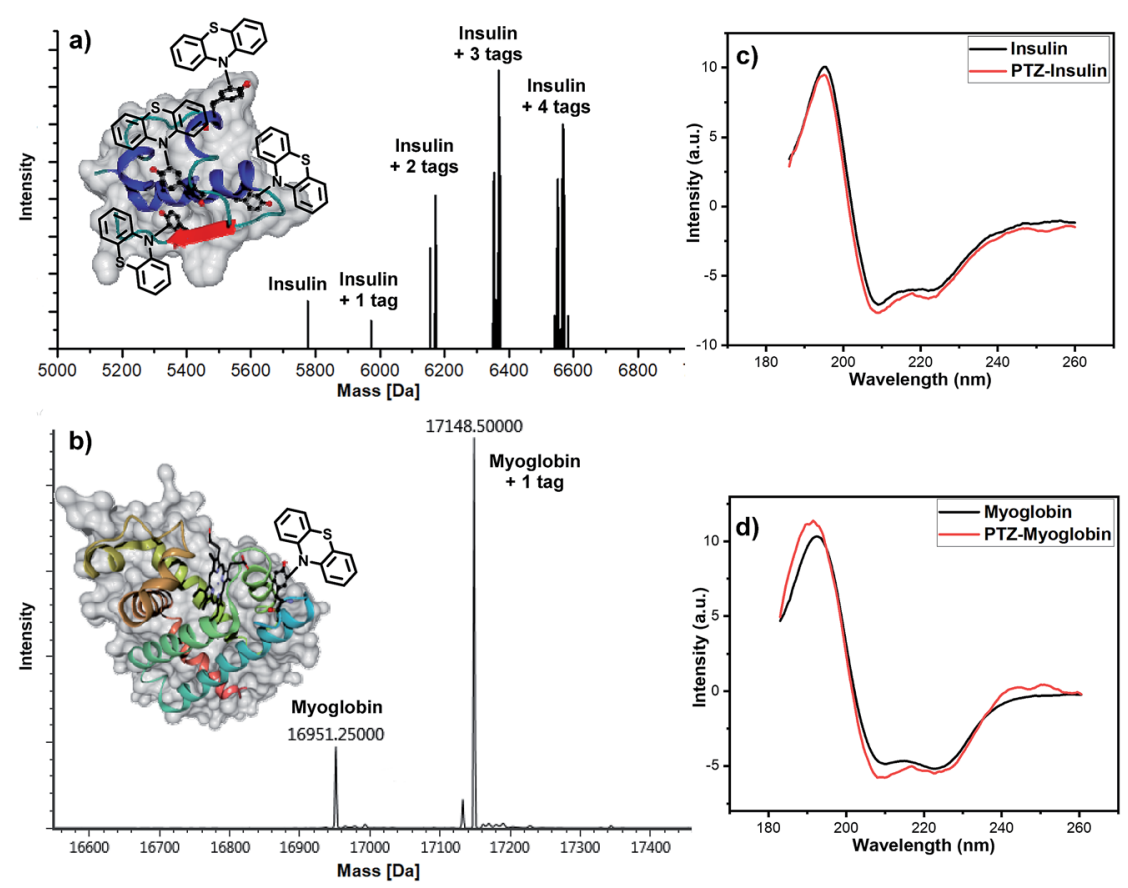

Fig. 3 Electrochemical modification of proteins. Reaction conditions for the bioconjugation of insulin: graphite rod anode, nickel plate cathode, constant current $=10 \mathrm{~mA}$, insulin ( $5 \mathrm{mg}$ ), phenothiazine $(10 \mathrm{mg}), \mathrm{CH}_{3} \mathrm{CN} / \mathrm{PBS}(\mathrm{pH}=7.3)(0.75 \mathrm{~mL} / 0.75 \mathrm{~mL})$, room temperature, $\mathrm{N}_{2}$, and $30 \mathrm{~min}$. Reaction conditions for the bioconjugation of myoglobin: graphite rod anode, nickel plate cathode, constant current $=0.5 \mathrm{~mA}$, $\mathrm{myoglobin}(5$ $\mathrm{mg}$ ), phenothiazine $(20 \mathrm{mg}), \mathrm{CH}_{3} \mathrm{CN} / \mathrm{PBS}(\mathrm{pH}=7.3)\left(0.75 \mathrm{~mL} / 0.75 \mathrm{~mL}\right.$ ), $-20{ }^{\circ} \mathrm{C}, \mathrm{N}_{2}$, and $15 \mathrm{~min}$. (a) Maldi-Tof MS analysis of modified insulin. (b) LC-MS analysis of modified myoglobin. (c) Effect of electrolytic arylamination on the structure of insulin. (d) Effect of electrolytic arylamination on the structure of myoglobin. 
manner. It is particularly noteworthy that this protocol provides a direct access to late-stage derivatization of valuable drugs (Fig. 2). For instance, when the biotin-containing phenothiazine $\mathbf{2 h}$ and probenecid-containing (uricosuric drugs) phenothiazine 2i were introduced to react with pentapeptide YAGFL $6 \mathbf{b}$, respectively, the desired products $7 \mathbf{i}$ and $7 \mathbf{j}$ could be obtained. Noticeably, these reactions were permitted by the direct electrooxidative bioconjugation reaction, and exhibit a remarkable substituent tolerance. In addition, to demonstrate that the phenothiazine-labelled peptide might be utilized as a fluorophore, molecule $7 \mathbf{k}$ from the reaction of 2 -acetylphenothiazine 2e and RGDFY 6a was prepared. The photograph showed that phenothiazine-modified peptide $\mathbf{7 k}$ apparently presented the ability of fluorescence emission under irradiation of UV light, clearly indicating that phenothiazine labelled biomolecules had the potential to be a possible biological fluorophore.

Afterward, we turned to discover the modification of proteins. Two proteins, insulin and myoglobin, containing at least one exposed tyrosine on the protein surface were electrolyzed with phenothiazine. When an excess amount of phenothiazine was added to the solution of insulin under electrolysis, four potentially reactive tyrosine residues on insulin were all tagged (Fig. 3a). Next, we tested the feasibility of our developed method for a larger protein, myoglobin. The electro-oxidative bioconjugation could be well performed within $15 \mathrm{~min}$ and generate single phenothiazine tagged myoglobin at $-20{ }^{\circ} \mathrm{C}$ (Fig. 3b). Importantly, CD spectroscopy revealed that the electrochemical methodology had negligible influence on the structure of both insulin and myoglobin (Fig. 3c and d). These satisfactory results revealed that the exposed tyrosine could be well-tagged by phenothiazine under our electro-oxidative conditions without decomposition.

\section{Conclusions}

By introducing organic electrochemistry, tyrosine residues can be well-labelled with phenothiazine derivatives with high chemo- and site-selectivity as well as excellent conversion under mild conditions. This strategy has been successfully applied to the modification of valuable biomolecules such as polypeptides, insulin and myoglobin. Moreover, this technique could promote the development of safer and more biological sustainable bioconjugation reactions that are operated under metal-, oxidant- and additive free conditions. We anticipate that advances in electrochemically induced bioconjugation will lead to an expanding library of interdisciplinary methodologies.

\section{Experimental}

A general procedure for bioconjugation of tyrosine and phenothiazine derivatives: in an oven-dried undivided threenecked bottle $(25 \mathrm{~mL})$ equipped with a stir bar, protected tyrosine $(0.20 \mathrm{mmol})$, phenothiazine $(0.24 \mathrm{mmol}), \mathrm{Na}_{2} \mathrm{SO}_{4}(0.40$ $\mathrm{mmol})$ and $\mathrm{CH}_{3} \mathrm{CN} / \mathrm{H}_{2} \mathrm{O}(6 \mathrm{~mL} / 4 \mathrm{~mL})$ were combined and added. The bottle was equipped with a graphite $\operatorname{rod}(\phi 6 \mathrm{~mm}$, about $15 \mathrm{~mm}$ immersion depth in solution) as the anode and a nickel plate $(15 \mathrm{~mm} \times 15 \mathrm{~mm} \times 1.0 \mathrm{~mm})$ as the cathode and then charged with nitrogen. The reaction mixture was stirred and electrolyzed at a constant current of $10 \mathrm{~mA}$ under room temperature for $75 \mathrm{~min}(2.3 \mathrm{~F})$. When the reaction was finished, the reaction mixture was extracted with ethyl acetate $(10 \mathrm{~mL} \times$ 3 ). The organic layers were combined, dried over $\mathrm{Na}_{2} \mathrm{SO}_{4}$, and concentrated. The pure product was obtained by flash column chromatography on silica gel (dichloromethane : methanol = $100: 1)$.

\section{Conflicts of interest}

There are no conflicts to declare.

\section{Acknowledgements}

This work was supported by the National Natural Science Foundation of China (21701127, 21520102003, and 21390402), the Hubei Province Natural Science Foundation of China (2017CFB152 and 2017CFA010), the Fundamental Research Funds for the Central Universities (213413000050), and the Scientific Research Foundation of Wuhan University (413100043 and 413100021). The Program of Introducing Talents of Discipline to Universities of China (111 Program) is also appreciated.

\section{Notes and references}

1 (a) C. D. Spicer and B. G. Davis, Nat. Commun., 2014, 5, 4740; (b) O. Boutureira and G. J. L. Bernardes, Chem. Rev., 2015, 115, 2174; (c) O. Koniev and A. Wagner, Chem. Soc. Rev., 2015, 44, 5495; (d) Q.-Y. Hu, F. Berti and R. Adamo, Chem. Soc. Rev., 2016, 45, 1691; (e) K. Kubota, P. Dai, B. L. Pentelute and S. L. Buchwald, J. Am. Chem. Soc., 2018, 140, 3128; $(f)$ D. T. Cohen, C. Zhang, C. M. Fadzen, A. J. Mijalis, L. Hie, K. D. Johnson, Z. Shriver, O. Plante, S. J. Miller, S. L. Buchwald and B. L. Pentelute, Nat. Chem., 2019, 11, 78.

2 (a) P. Akkapeddi, S.-A. Azizi, A. M. Freedy, P. M. S. D. Cal, P. M. P. Gois and G. J. L. Bernardes, Chem. Sci., 2016, 7, 2954; (b) X. Chen and Y.-W. Wu, Org. Biomol. Chem., 2016, $14,5417$.

3 N. S. Joshi, L. R. Whitaker and M. B. Francis, J. Am. Chem. Soc., 2004, 126, 15942.

4 (a) E. M. Sletten and C. R. Bertozzi, Angew. Chem., Int. Ed., 2009, 48, 6974; (b) A. F. M. Noisier and M. A. Brimble, Chem. Rev., 2014, 114, 8775; (c) Y. Seki, T. Ishiyama, D. Sasaki, J. Abe, Y. Sohma, K. Oisaki and M. Kanai, J. Am. Chem. Soc., 2016, 138, 10798; (d) J. Wang, S. Zheng, Y. Liu, Z. Zhang, Z. Lin, J. Li, G. Zhang, X. Wang, J. Li and P. R. Chen, J. Am. Chem. Soc., 2016, 138, 15118; (e) J. N. deGruyter, L. R. Malins and P. S. Baran, Biochemistry, 2017, 56, 3863; $(f)$ W. Zhao, H. G. Lee, S. L. Buchwald and J. M. Hooker, J. Am. Chem. Soc., 2017, 139, 7152.

5 (a) G. Lautrette, F. Touti, H. G. Lee, P. Dai and B. L. Pentelute, J. Am. Chem. Soc., 2016, 138, 8340; (b) J. Willwacher, R. Raj, S. Mohammed and B. G. Davis, J. Am. Chem. Soc., 2016, 138, 8678; (c) H. G. Lee, G. Lautrette, B. L. Pentelute and 
S. L. Buchwald, Angew. Chem., Int. Ed., 2017, 56, 3177; (d) A. J. Rojas, C. Zhang, E. V. Vinogradova, N. H. Buchwald, J. Reilly, B. L. Pentelute and S. L. Buchwald, Chem. Sci., 2017, 8, 4257; (e) M. J. Matos, B. L. Oliveira, N. MartínezSáez, A. Guerreiro, P. M. S. D. Cal, J. Bertoldo, M. Maneiro, E. Perkins, J. Howard, M. J. Deery, J. M. Chalker, F. Corzana, G. Jiménez-Osés and G. J. L. Bernardes, J. Am. Chem. Soc., 2018, 140, 4004; (f) K. Yamatsugu, M. Furuta, S. Xi, Y. Amamoto, J. Liu, S. A. Kawashima and M. Kanai, Bioorg. Med. Chem., 2018, 26, 5359.

6 (a) S. Chen, X. Li and H. Ma, ChemBioChem, 2009, 10, 1200; (b) H. Ban, J. Gav rilyuk and C. F. Barbas, J. Am. Chem. Soc., 2010, 132, 1523; (c) A. M. ElSohly and M. B. Francis, Acc. Chem. Res., 2015, 48, 1971; (d) X. Wu, X. Li, H. Li, W. Shi and H. Ma, Chem. Commun., 2017, 53, 2443.

7 D. W. Romanini and M. B. Francis, Bioconjugate Chem., 2008, 19, 153.

8 S. D. Tilley and M. B. Francis, J. Am. Chem. Soc., 2006, 128, 1080.

9 (a) S. Sato and H. Nakamura, Angew. Chem., Int. Ed., 2013, 52, 8681; (b) S. Sato, K. Hatano, M. Tsushima and H. Nakamura, Chem. Commun., 2018, 54, 5871.

10 (a) H. Ban, M. Nagano, J. Gavrilyuk, W. Hakamata, T. Inokuma and C. F. Barbas, Bioconjugate Chem., 2013, 24, 520; (b) Q.-Y. Hu, M. Allan, R. Adamo, D. Quinn, H. Zhai, G. Wu, K. Clark, J. Zhou, S. Ortiz, B. Wang, E. Danieli, S. Crotti, M. Tontini, G. Brogioni and F. Berti, Chem. Sci., 2013, 4, 3827; (c) C. M. Madl and S. C. Heilshorn, Bioconjugate Chem., 2017, 28, 724; (d) S. Sato, K. Nakamura and H. Nakamura, ChemBioChem, 2017, 18, 475; (e) D. Alvarez-Dorta, C. Thobie-Gautier, M. Croyal, M. Bouzelha, M. Mével, D. Deniaud, M. Boujtita and S. G. Gouin, J. Am. Chem. Soc., 2018, 140, 17120.

11 (a) J. Gavrilyuk, H. Ban, M. Nagano, W. Hakamata and C. F. Barbas, Bioconjugate Chem., 2012, 23, 2321; (b) M. W. Jones, G. Mantovani, C. A. Blindauer, S. M. Ryan, X. Wang, D. J. Brayden and D. M. Haddleton, J. Am. Chem. Soc., 2012, 134, 7406; (c) A.-W. Struck, M. R. Bennett, S. A. Shepherd, B. J. C. Law, Y. Zhuo, L. S. Wong and J. Micklefield, J. Am. Chem. Soc., 2016, 138, 3038; (d) S. Vandewalle, R. De Coen, B. G. De Geest and F. E. Du Prez, ACS Macro Lett., 2017, 6, 1368; (e) N. Ichiishi,
J. P. Caldwell, M. Lin, W. Zhong, X. Zhu, E. Streckfuss, H.-Y. Kim, C. A. Parish and S. W. Krska, Chem. Sci., 2018, 9, 4168; $(f)$ J. Ohata, M. K. Miller, C. M. Mountain, F. Vohidov and Z. T. Ball, Angew. Chem., Int. Ed., 2018, 57, 2827.

12 K. L. Seim, A. C. Obermeyer and M. B. Francis, J. Am. Chem. Soc., 2011, 133, 16970.

13 (a) J. B. Sperry and D. L. Wright, Chem. Soc. Rev., 2006, 35, 605; (b) A. Jutand, Chem. Rev., 2008, 108, 2300; (c) J.-i. Yoshida, K. Kataoka, R. Horcajada and A. Nagaki, Chem. Rev., 2008, 108, 2265; (d) H.-C. $\mathrm{Xu}$ and K. D. Moeller, J. Am. Chem. Soc., 2010, 132, 2839; (e) S. R. Waldvogel and S. Möhle, Angew. Chem., Int. Ed., 2015, 54, 6398; $(f)$ Z.-W. Hou, Z.-Y. Mao, H.-B. Zhao, Y. Y. Melcamu, X. Lu, J. Song and H.-C. Xu, Angew. Chem., Int. Ed., 2016, 55, 9168; (g) N. Fu, G. S. Sauer, A. Saha, A. Loo and S. Lin, Science, 2017, 357, 575; $(h)$ K. Liu, S. Tang, P. Huang and A. Lei, Nat. Commun., 2017, 8, 775; (i) N. Sauermann, T. H. Meyer, C. Tian and L. Ackermann, J. Am. Chem. Soc., 2017, 139, 18452; (j) M. Yan, Y. Kawamata and P. S. Baran, Chem. Rev., 2017, 117, 13230; (k) Q.-L. Yang, Y.-Q. Li, C. Ma, P. Fang, X.-J. Zhang and T.-S. Mei, J. Am. Chem. Soc., 2017, 139, 3293; (l) H.-B. Zhao, Z.-W. Hou, Z.-J. Liu, Z.-F. Zhou, J. Song and H.-C. Xu, Angew. Chem., Int. Ed., 2017, 56, 587; (m) Y. Jiang, K. Xu and C. Zeng, Chem. Rev., 2018, 118, 4485; (n) K. D. Moeller, Chem. Rev., 2018, 118, 4817; (o) M. Rafiee, F. Wang, D. P. Hruszkewycz and S. S. Stahl, J. Am. Chem. Soc., 2018, 140, 22; (p) G. S. Sauer and S. Lin, ACS Catal., 2018, 8, 5175; (q) S. Tang, Y. Liu and A. Lei, Chem, 2018, 4, 27; (r) S. Tang, S. Wang, Y. Liu, H. Cong and A. Lei, Angew. Chem., Int. Ed., 2018, 57, 4737; (s) K.-Y. Ye, G. Pombar, N. Fu, G. S. Sauer, I. Keresztes and S. Lin, J. Am. Chem. Soc., 2018, 140, 2438; $(t)$ J.-i. Yoshida, A. Shimizu and R. Hayashi, Chem. Rev., 2018, 118, 4702.

14 (a) S. P. Massie, Chem. Rev., 1954, 54, 797; (b) M. J. Ohlow and B. Moosmann, Drug Discovery Today, 2011, 16, 119; (c) X. Pan, C. Fang, M. Fantin, N. Malhotra, W. Y. So, L. A. Peteanu, A. A. Isse, A. Gennaro, P. Liu and K. Matyjaszewski, J. Am. Chem. Soc., 2016, 138, 2411; (d) J. Yang, X. Zhen, B. Wang, X. Gao, Z. Ren, J. Wang, Y. Xie, J. Li, Q. Peng, K. Pu and Z. Li, Nat. Commun., 2018, 9, 840. 